\author{
Paula Kacprzak, Justyna WaWrzynek, Angelika SŁomska
}

\author{
Zakład Badań Planktonu Morskiego \\ Instytut Oceanografii \\ Uniwersytet Gdański \\ Al. Marszałka Pitsudskiego 46, 81-378 Gdynia \\ E-mail: paula.kacprzak@phdstud.ug.edu.pl
}

\title{
ZOOPLANKTON W EKOSYSTEMACH POLARNYCH - WYZWANIA I PROGNOZY W OBLICZU ZMIAN KLIMATU
}

\begin{abstract}
GENEZA I KONSEKWENCJE ZMIAN KLIMATU W REJONACH POLARNYCH

Zmiany klimatu, powodujace przekształcenia parametrów fizycznych i chemicznych wód morskich, maja niepodważalny wpływ na funkcjonowanie całych ekosystemów. Oceany pochłaniaja 30\% atmosferycznego $\mathrm{CO}_{2}$ emitowanego od okresu Rewolucji Przemysłowej (SABINE i FEELY 2007), co powoduje znaczace zmiany w chemizmie wód morskich, a tym samym widoczne ich zakwaszanie. Podwyższone ciśnienie parcjalne $\mathrm{CO}_{2}$ $\left(\mathrm{pCO}_{2}\right.$ ciśnienie jednostkowe danego gazu na jednostke powierzchni) obniża $\mathrm{pH}$ wód $\mathrm{i}$ ich wysycenie węglanem wapnia $\left(\mathrm{CaCO}_{3}\right)$. Międzyrzadowy Panel ds. Zmian Klimatu (IPCC 2013) podaje, iż do 2100 r. pH wód spadnie średnio o 0,13-0,42 jednostek, w zależności od scenariuszy zmian klimatu. Przewiduje się również, że poziom wysycenia $\mathrm{CaCO}_{3}$ w oceanach będzie przebiegał coraz bliżej powierzchni, szczególnie w rejonach polarnych, gdzie zdolność buforowa jest mniejsza ze względu na wpływ wody słodkiej $z$ topniejacego lodu morskiego (FEELY i współaut. 2004). Rejony wysokich szerokości geograficznych charakteryzuja się naturalnie niska koncentracją jonów węglanowych, między innymi w związku ze zwiększona rozpuszczalnością $\mathrm{CO}_{2} \mathrm{i}$ intensywnym mieszaniem wód. W rezultacie, stopień nasycenia wód morskich węglanem wapnia $\left(\mathrm{CaCO}_{3}\right)$ jest niższy w rejonach polarnych, w stosunku do umiarkowanych $i$ niskich szerokości geograficznych. Prognozuje się, iż w wodach powierzchniowych niektórych obszarów północnych mórz polarnych wystapi niedosycenie
\end{abstract}

aragonitem (mniej stabilna forma węglanu wapnia) (BATEs i współaut. 2009). Zgodnie $z$ aktualnym tempem emisji $\mathrm{CO}_{2}$, szacuje sie, że powierzchniowe wody Oceanu Południowego i Arktycznego oraz części subarktycznej Pacyfiku, zostaną niedosycone aragonitem pod koniec tego wieku (FEELY i współaut. 2009). Obserwacje i badania rejonów polarnych dały początek głęsszej analizie wpływu zakwaszania wód, również $\mathrm{w}$ rejonach tropikalnych i umiarkowanych, na funkcjonowanie zooplanktonu i jego rozmieszczenie. Gwałtowne i wysokie tempo zmian wpłynęło na intensyfikację badań, mających na celu określenie ich wpływu na procesy fizjologiczne oraz możliwości aklimatyzacyjne $\mathrm{i}$ adaptacyjne organizmów i całych populacji.

Okalający Antarktydę Ocean Południowy jest głównym rejonem absorbowania antropogenicznej emisji $\mathrm{CO}_{2}$, ze względu na swoje olbrzymie rozmiary (KHATIWALA i współaut. 2009). Poniżej $60^{\circ} \mathrm{S}$, średnia głębokość poziomu wysycenia aragonitem wynosi około 730 m (ORR i współaut. 2005), jednak scenariusze przewidują stopniowe jej zmniejszanie. W przypadku Oceanu Arktycznego, oprócz postępującego procesu zakwaszania wód, obserwuje się również zmniejszenie zasięgu lodu morskiego oraz zwiększone tempo produkcji pierwotnej, szczególnie w obszarach szelfowych (BATEs i współaut. 2009). Procesy te redukuja ciśnienie parcjalne $\mathrm{CO}_{2} \mathrm{w}$ wodach powierzchniowych, co powoduje utworzenie warstwy wód wymieszanej i niedosyconej atmosferycznym $\mathrm{CO}_{2}$. Gwaltowne zmniejszenie pokrywy lodowej $\mathrm{w}$ okresie letnim wydłuża ekspozycję wód na czynniki atmosferyczne 
oraz powoduje pochłanianie przez warstwe powierzchniową wód więcej $\mathrm{CO}_{2}$. Oznacza to, $\dot{z}$ e topnienie pokrywy lodowej redukuje poziom nasycenia wód $\mathrm{CaCO}_{3}$, głównie przez obniżenie pH (STEINACHER i współaut. 2009).

Ocean Światowy doświadcza obecnie wielu znaczących zmian, wśród których, prócz zmieniajacej się gospodarki węglanowej, rejestruje się również ocieplanie wód morskich. W zwiąku ze zwiększona ilościa absorbowanego ciepła przez wody oceaniczne, temperatura powierzchniowa wód Oceanu Światowego wzrasta o około $0,11^{\circ} \mathrm{C}$ na dekadę (IPCC 2013). Najbardziej narażone sa powierzchniowe warstwy wód, przeważnie od 0 do $75 \mathrm{~m}$ głębokości, co powoduje powstanie wyraźnego gradientu gęstości wody morskiej, a tym samym silna stratyfikacje $w$ górnych warstwach oceanu (GRUBER 2011). Powodujacy ocieplenie $\mathrm{CO}_{2}$ przenika głębiej w północnym Atlantyku niż w północnym Pacyfiku, Oceanie Indyjskim czy $\mathrm{w}$ południowych częściach oceanów (BARNETT i współaut. 2005). Jednak najbardziej drastyczne ocieplenie rejestruje się w rejonach tropikalnych i polarnych (GRUBER 2011). Od lat 50. XX w. w rejonie Półwyspu Antarktycznego odnotowano największy wzrost temperatury wód powierzchniowych na półkuli południowej (TURNER i współaut. 2016). Ocieplenie to przyczyniło się m.in. do topnienia lodowców, dezintegracji pływającego lodu morskiego, czy pojawienia się obcych gatunków roślin lądowych w tym rejonie. Sugeruje się, iż ocieplenie to było procesem współistniejącym ze zmniejszeniem warstwy ozonowej w stratosferze, lokalnym zanikaniem lodu morskiego, zwiększeniem udziału i intensywności wiatrów zachodnich, a także modyfikacja siły i lokalizacji atmosferycznej cyrkulacji pomiędzy niskimi i wysokimi szerokościami geograficznymi (TURNER i współaut. 2016). Z kolei w latach 90. XX w., średnia roczna temperatura zmniejszyła się istotnie, szczególnie w okresie australijskiego lata. Oziębienie to było prawdopodobnie konsekwencja zwiększenia intensywności wiatrów wschodnich lub wschodnio-południowych, co w rezultacie spowodowało nasilenie cyrkulacji w północnej części Morza Weddella i wzmocnienie strumienia przepływu wód $z$ umiarkowanych szerokości geograficznych. Doniesienia te potwierdzaja poglą, iż 10-letnie zmiany temperatury w rejonie Półwyspu Antarktycznego nie wynikają głównie $z$ działajacych globalnie czynników powodujących zmiany temperatury, a raczej ukazuja naturalna zmienność lokalną, wynikajacca $z$ regionalnej cyrkulacji atmosferycznej (TURNER i współaut. 2016). Powierzchniowa temperatura w Morzu Weddella jest niższa o $2^{\circ} \mathrm{C}$ w porównaniu ze średnia wieloletnia, podczas gdy w rejonie Georgii Południowej nastapił efekt odwrotny
- odnotowano ocieplenie wód o $2^{\circ} \mathrm{C}$ (BRIERLEY i KINGSFORD 2009). W przypadku Cieśniny Drake'a pomiary temperatury w okresie 30 lat dały zaskakujace wyniki: warstwy wód poniżej $700 \mathrm{~m}$ ociepliły się w tym okresie o $0,6^{\circ} \mathrm{C}$, podczas gdy $\mathrm{w}$ tym samym czasie wody powierzchniowe ochłodziły się o $2,1^{\circ} \mathrm{C}$. Jednocześnie, nawiązujac do modeli zmian klimatu, wysycenie wód oceanicznych tlenem może spaść nawet o 1-7\% w następnych 100 latach (KEELING i współaut. 2010). Opisane wyżej zjawiska moga mieć niebywały wpływ na fizjologię, procesy życiowe organizmów zmiennocieplnych, a zwłaszcza żyjacych w rejonach polarnych (SEIBEL 2011, MAAS i współaut. 2012).

Prognozy zmian w pelagicznych ekosystemach, szczególnie polarnych, zakładaja bardzo poważne konsekwencje dla zasiedlajacych je organizmów. Rosnaca temperatura jest jednym $z$ najważniejszych czynników modyfikujacych rozmieszczenie gatunków i zasięgi ich występowania, jak również zaburzajacych okres wzmożonej produkcji pierwotnej. Co więcej, wpływa to również na procesy fizjologiczne, reprodukcyjne i ontogenezę organizmów. Pod wpływem niekorzystnych warunków środowiska liczebność grup reprezentujacych niższe poziomy troficzne (np. kryl antarktyczny) spada, a co za tym idzie, konsumenci wyższych rzędów (np. pingwiny Adeli) sa reprezentowani przez mniejszą liczbę osobników (BRIERLEY i KINGSFORD 2009). Szczególnie w Arktyce, zmniejszająca się W ostatnich kilkudziesięciu latach pokrywa lodu morskiego powoduje zanikanie habitatów i zagrożenie dla niektórych gatunków, takich jak foki czy niedźwiedzie polarne (BRIERLEY i KINGSFORD 2009). Ekosystem Antarktyki również znajduje się pod wpływem działania nadmiaru $\mathrm{CO}_{2}$, powodujacego stopniowe zakwaszenie wód. $\mathrm{Na}$ funkcjonowanie Oceanu Południowego wpływa również eksploatacja zasobów naturalnych czy pojawianie się gatunków inwazyjnych. Postępujace w tym rejonie zakwaszenie negatywnie wpływa na organizmy posiadajace wapienny szkielet, jak również może utrudniać rozwój i rozmnażanie kryla. Ocieplajace się wody Antarktyki powoduja, że w sieci troficznej swój udział coraz częściej maja gatunki inwazyjne, takie jak kraby, które jako drapieżniki o dużym potencjale reprodukcyjnym, moga zaburzyć funkcjonowanie populacji gatunków rodzimych (CHOwn i współaut. 2015). Równie poważnym problemem, będacym jednak konsekwencją wspomnianych procesów, zdaje się być cielenie ogromnych gór lodowych w rejonie Antarktyki. Morze Rossa, zlokalizowane na szelfie kontynentalnym Antarktyki, jest jednym $z$ najbardziej produktywnych rejonów Oceanu Południowego. Morze 
to, $z$ licznymi obszarami wolnymi od lodu morskiego, znajdującymi się zwykle w jego centrum, jest niezwykle cennym miejscem, gdzie w okresie wiosennym pojawiają się intensywne zakwity fitoplanktonu (ARRIGO i współaut. 2002). W wyniku tak wysokiej produktywności, Morze Rossa jest rejonem różnorodnym ze względu na liczne populacje należace do wyższych poziomów troficznych, takich jak ssaki morskie czy ptaki. W istocie, 25\% populacji pingwina cesarskiego i $30 \%$ populacji pingwina Adeli tworzy kolonie właśnie w obszarze Morza Rossa. Podczas prowadzonych w latach 2000-2001 badań ujawniono, że góry lodowe o większej powierzchni przyczyniły się do istotnego opóźnienia zakwitu fitoplanktonu i zredukowały proces produkcji pierwotnej o 95\% (ARRIGO i współaut. 2002). Modyfikacje dynamiki produkcji pierwotnej, spowodowane $\mathrm{m}$. in. tworzeniem barier przez dryfujące góry lodowe, które uniemożliwiają wycofanie się $z$ danego obszaru lodu morskiego, moga wpływać na cały ekosystem pelagialu Morza Rossa. Często, ze względu na różne wymagania gatunków fitoplanktonu względem światła czy dostępnych substancji odżywczych, następuje istotna zmiana w strukturze całego zespołu. Jedne gatunki zastępowane sa innymi, mniej wymagajacymi, co wpływa na wyższe poziomy troficzne. Należące do zooplanktonu widłonogi (cykl życiowy niektórych gatunków jak np. Calanus hyperboreus przekracza 4 lata (HIRche 1997)) i kryl (długość życia Euphausia superba wynosi min. 5 lat) (PAKHOMOV 2011), zużywają zapasy w postaci tłuszczów zgromadzonych $z$ poprzedniego sezonu, aby złożyć jaja podczas zakwitu fitoplanktonu. Jego opóźnienie spowoduje zmniejszenie źródła pokarmu dla młodocianych osobników należących do zooplanktonu, lub przesunięcie reprodukcji, co może skutkować uszczupleniem zasobów tłuszczowych niezbędnych do wylęgu jaj. Wszystkie wspomniane sytuacje moga $\mathrm{w}$ efekcie przyczynić się do zaburzeń w procesie rozmnażania m.in. pingwinów i narażenie ich młodych na stres związany $z$ mniejsza dostępnościa pokarmu (ARRIGO i współaut. 2002). Ze względu na przebudowę sieci troficznej i mniejsze zagęszczenia kryla stanowiacego główne źródło pożywienia tych ptaków, śmiertelność młodych osobników jest wyższa. Co więcej, w wyniku intensywniejszych poszukiwań pokarmu przez dorosłe osobniki i konieczności pokonywania coraz większych odległości w celu poszukiwania pożywienia, struktura populacji ulega przekształceniom (POLOCZAŃSKA i współaut. 2016).

Rosnace gwałtownie zainteresowanie wpływem zakwaszania wód oceanicznych na ekosystemy morskie spowodowało pojawienie się bardzo licznych doniesień związanych $z$ odpowiedziami organizmów na te procesy. Badania udowodniły, że większa śmiertelność po ekspozycji na wody o niższym pH dotyczyła głównie koralowców, mięczaków i szkarłupni, podczas gdy zahamowanie procesu kalcyfikacji wystapiło u koralowców, kokolitoforów i mięczaków (od 22 do 39\%) (KROEKER i współaut. 2013). Badania te dowodzą złożoności problemu i ujawniaja szeroki wpływ zakwadzenia na różnorodność organizmów morskich. Co więcej, niektóre $z$ grup, takie jak skorupiaki, ryby, trawy morskie czy okrzemki, nie wykazuja negatywnych odpowiedzi w odniesieniu do procesów fizjologicznych (np. wzrost), pod wpływem zakwaszania wód, a często nawet czerpią pewne korzyści, np. zwiększając tempo wzrostu (trawy morskie), powodujące ekspansje na nowe tereny. Przypuszcza się, że bardziej ruchliwe organizmy takie jak skorupiaki czy ryby moga być mniej wrażliwe na zakwaszanie wód, podczas gdy niektóre osiadłe algi czy okrzemki moga czerpać wspomniane korzyści $z$ obniżonego pH wód. Co więcej, rozpatrujac wpływ zmian klimatu na dany organizm należy uwzględnić również jego wrażliwość w poszczególnych stadiach rozwoju. W przypadku wielu $z$ nich, jak np. mięczaki czy szkarłupnie, larwy i osobniki młodociane maja zdecydowanie mniejsza tolerancję na zmieniajace się warunki środowiska (KROEKER i współaut. 2013).

Zachodzace zmiany klimatu mają również istotny wpływ na konsumentów wyższych rzędów, jak np. ptaki morskie. Mniejszy sukces reprodukcyjny zaobserwowany został u północnoatlantyckich gatunków ptaków $\mathrm{m}$. in. fulmarów, burzyków północnych czy mew trójpalczastych. Jest to głównie wynik przekształceń sieci troficznej powodowanych ociepleniem wód, a co za tym idzie utrudnionej dostępności pokarmu. $Z$ powodu ocieplających się wód, zmniejsza się również liczebność organizmów zimnolubnych, natomiast organizmy ciepłolubne sa notowane coraz częściej. Dotyczy to między innymi wystepujących na skalistym wybrzeżu pakli zimnolubnych $z$ gatunku Semibalanus balanoides, które zastępowane są przez ciepłolubny gatunek $z$ rodzaju Chthamalus. Według prognoz, S. balanoides wyginie całkowicie w tym rejonie najpóźniej do 2050 r. (Poloczanska i współaut. 2016).

\section{FUNKCJONOWANIE ORGANIZMÓW ZOOPLANKTONOWYCH W OBLICZU PROCESU ZAKWASZENIA I OCIEPLENIA WOD}

W ostatnich latach zainteresowanie problematyka zmian klimatu, szczególnie w 
rejonach polarnych, istotnie wzrosło. Konsekwencja tego stały się coraz liczniejsze badania całych zespołów organizmów zooplanktonowych, które, znajdując się na niższym poziomie troficznym, daja niemal natychmiastowy sygnał w przypadku zachodzacych w ekosystemie przekształceń. Badania dotyczace wpływu zakwaszania wód na funkcjonowanie organizmów morskich ujawniły, że w przypadku wielu grup takie procesy jak przeżywalność, wzrost, kalcyfikacja, rozwój ontogenetyczny, a także liczebność zostały istotnie zredukowane (PoLOCZANSKA i współaut. 2016). Co więcej, okazuje się, że większa wrażliwość organizmów na zakwaszenie ujawnia się przy jednoczesnym współwystępowaniu podwyższonej temperatury w danym rejonie. Wiele grup organizmów zooplanktonowych doświadcza skutków tych zmian, czego konsekwencja jest między innymi przesuwanie zasięgów występowania zwierząt i migracje do rejonów bardziej sprzyjajacych ich prawidłowemu funkcjonowaniu i rozwojowi. Wymienione sposoby radzenia sobie ze stresem wynikaja zwykle $z$ preferencji ekologicznych i stenotermiczności, natomiast duże liczebności czy swobodne unoszenie się w toni wodnej umożliwiają zooplanktonowi dużo szybszą reakcję na niekorzystne warunki, w porównaniu $z$ np. organizmami osiadłymi (POLOCZANSKA i współaut. 2016). Tak więc, ich rozmieszczenie przestrzenne uzależnione jest w dużej mierze od parametrów otaczającego środowiska. Ma to swoje odzwierciedlenie w kształtowaniu sieci troficznej; gatunki tolerujące wyższe temperatury wód charakteryzuja się mniejszymi rozmiarami ciała, w stosunku do przebywajacych w wodach zimnych, między innymi ze względu na różną gęstość wód. Jednocześnie, ze względu na ekstremalne warunki panujace $w$ rejonach polarnych, organizmy zooplanktonowe zmuszone sa do gromadzenia dużych ilości substancji zapasowych jakimi sa cenne kwasy tłuszczowe. W zwiazku $z$ tym, obserwowana w ostatnich latach ekspansja borealnego gatunku widłonoga Calanus finmarchicus w rejony wysokiej Arktyki, wraz $z$ jednoczesnym zmniejszeniem liczebności arktycznego Calanus glacialis, prowadzi do zmniejszenia kaloryczności pożywienia dla ptaków morskich, szczególnie alczyków, ponieważ C. glacialis jest niezwykle cennym źródłem pokarmu (wyższa w porównaniu do C. finmarchicus zawartość związków przyswajalnych) (ScOTT i współaut. 2000, WEYDMANN i współaut. 2012). BEAUGRAND i KIRBY (2010) dostrzegli również negatywna korelację pomiędzy prawdopodobieństwem wystapienia dorsza w Morzu Północnym a różnorodnością gatunkowa widłonogów. Narybek dorsza ma szansę przetrwać, jeśli w jego diecie oprócz małego gatunku widłonoga Pseudocalanus spp., znajda się przede wszystkim większe gatunki jak Calanus finmarchicus.

Podobnie jak w przypadku konsumentów wyższych rzędów, organizmy zooplanktonowe również doświadczają zmian związanych $z$ ociepleniem wód. Najczęstsza odpowiedź na przekształcenia w strukturze mas wodnych, to przesuwanie granic występowania danych gatunków. W Oceanie Południowym, zasięg i okres występowania lodu morskiego, podobnie jak temperatura, maja wpływ na przebieg produkcji pierwotnej. Badania wskazuja na potencjalne zagrożenie dla sieci troficznych wynikajace ze zmiany w dystrybucji producentów takich jak kokolitofory, okrzemki czy też mniejsze pikocyjanobakterie $z$ rodzaju Synechococcus i Prochlorococcus. Ze względu na pełnienie ważnych funkcji (np. dostarczanie azotu do atmosfery, wiazanie krzemu, bardziej efektywne pobieranie substancji odżywczych przez pikoplankton) w obiegu nutrientów w środowisku, istotne jest monitorowanie ich zasięgu i zagęszczenia (DUTKIEWICZ i współaut. 2015). Zwiększony ładunek $\mathrm{CO}_{2}$, dostarczany do wód morskich wraz $z$ ich eutrofizacja, powoduja istotne fluktuacje w liczebności fitoplanktonu. Zmieniające się parametry wód maja wpływ również na dominujace gatunki producentów, co może skutkować przekształceniem struktury gatunkowej fitożerców. Wraz z wyższym $\mathrm{pH}$, liczebność osobników różnych gatunków zooplanktonu może ulec zmniejszeniu, co oznacza mniejszą efektywność żerowania na fitoplanktonie. Odpowiedzią niektórych gatunków wiciowców na większą kwasowość wód jest zaburzenie ich migracji pionowej, a tym samym np. wzrost śmiertelności żerujacych na nich widłonogów. Zmieniona produkcja pierwotna, zaburzona przez lokalne warunki fizyko-chemiczne, może potęgować występowanie zjawisk takich jak masowe zakwity toksycznych gatunków fitoplanktonu i powiększanie stref beztlenowych, co bezpośrednio przekłada się na zmniejszenie zasobów ryb poławianych komercyjnie (FLYNN i współaut. 2015). Liczne symulacje pokazuja, że zakwaszenie oceanów może mieć bardzo różny wpływ na fizjologię organizmów morskich, natomiast różnice w ich wielkości, aktywności metabolicznej czy tempie wzrostu zależeć będą raczej od czynników panujących w bezpośrednim otoczeniu organizmu (FLYNN i współaut. 2012). W południowo-zachodniej części Atlantyku liczebność kryla znacznie spadła (lata 1926-2003), podczas gdy ciepłolubne gatunki salp stały się w tych latach liczniejsze. Występowanie dużych zagęszczeń kryla jest uzależnione od sezonowego zakwitu fitoplanktonu i gatunków 
podlodowych, szczególnie podczas sezonu letniego. Oba te źródła pokarmu ograniczaja swoją liczebność w odpowiedzi na ocieplenie otaczajacych wód i zmniejszający się zasięg lodu (POLOCZANSKA i współaut. 2016). Obserwacje liczebności organizmów zooplanktonowych stanowia "system wczesnego ostrzegania" dla ewentualnych zmian zasięgów występowania gatunków w skali globalnej. Lokalne zmiany habitatów zaobserwowano do tej pory w różnych rejonach świata np.: południowo-wschodniej części wybrzeża Afryki, północno-zachodnim Pacyfiku, w północnej Zatoce Meksykańskiej i południowo-wschodniej Australii, co stanowi dowód na zmiany granic występowania danego gatunku w mniejszej skali. Najszybsze tempo zmian zaobserwowano w północno-wschodnim Atlantyku. W związu $\mathrm{z}$ ociepleniem, około 108 gatunków ciepłolubnych widłonogów przesunęło granice swojego występowania w kierunku bieguna północnego w tempie około $231,6 \mathrm{~km}$ na dekadę, $z$ jednoczesnym spadkiem liczebności organizmów zimnolubnych (PolocZANsKA i współaut. 2016)

W zwiazku z zaburzeniami gospodarki węglanowej, wynikajacymi $z$ postępującego zakwaszenia oceanu, wiele organizmów planktonowych odczuwa negatywne skutki tych zmian. Należą do nich głównie organizmy, których tkanki sa zbudowane częściowo $z$ węglanu wapnia, takie jak pelagiczne otwornice $z$ gatunku Globigerina bulloides czy kokolitofory, jak np. Emiliania huxleyi. Organizmy te w dużym stopniu odpowiadaja za obieg węgla i jego transport do głębszych stref oceanicznych, a w końcu zdeponowanie związków węgla na dnie. W zwiąku $z$ tym, jeśli ich liczebność zmaleje, szczególnie w wysokich szerokościach geograficznych, gdzie sa one zwykle liczne (np. subarktyczna część Pacyfiku), transport węgla organicznego w głębokie partie wód $z$ pewnościa zostanie zaburzony (SCHIEBEL, 2002). WEYDMANN i współaut. (2012) zaobserwowali, że mimo iż $\mathrm{CO}_{2}$ powodujący zakwaszenie wód, nie wpłynał istotnie na produkcje jaj $u$ widłonoga Calanus glacialis, to jednak spowodował opóźnienie wylęgu potomstwa. Badania GARZKE i współaut. (2016) sugeruja również, że populacje niektórych gatunków widłonogów, np. Paracalanus sp., Pseudocalanus sp., Oithona sp. czy Acartia sp., moga być bardziej narażone na działanie wyższej temperatury otaczających wód niż na postępujace zakwaszenie, natomiast niższe $\mathrm{pH}$ może modyfikować w sposób antagonistyczny lub synergistyczny wpływ temperatury na ich organizmy. Antagonistyczne działanie obu procesów było niekorzystne dla stadiów młodocianych widłonogów. Liczebność tych stadiów (naupliusów i kopepoditów), jak i dorosłych osobników, a także długość głowotułowia zdecydowanie zmniejszała się pod wpływem wyższej temperatury, podczas gdy obniżone $\mathrm{pH}$ często redukowało jej negatywne działanie. Również skład kwasów tłuszczowych zmieniał się wraz $z$ ociepleniem wód (GARZKE i współaut. 2016). Dzięki przeprowadzonym badaniom wiadomo, że nawet $\mathrm{w}$ obrębie jednego gatunku mamy do czynienia $z$ różnymi odpowiedziami, szczególnie dotyczy to licznych stadiów rozwojowych. W przypadku widłonoga Acartia tonsa, najwrażliwsze na podwyższone wartości $\mathrm{pCO}_{2}$ były naupliusy (wczesne stadium rozwojowe widłonoga), natomiast, co ciekawe, jaja, kopepodity (starsze stadia młodociane) oraz dorosłe samce i samice były w dobrej kondycji nawet po wpływem bardzo wysokich wartości $\mathrm{pCO}_{2}$ (powyżej $\left.3000 \mu \mathrm{atm}\right)$. Równie narażone na działanie obniżonego $\mathrm{pH}$ i fluktuacje temperatury sa ślimaki skrzydłonogie (Pteropoda), które przystosowały się do pelagicznego trybu życia, przekształcając noge w pterygopodia (skrzydełka) (Ryc. 1). Badania Pteropoda obejmuja zazwyczaj dwa rzędy: posiadajace muszlę Thecosomata i tzw. nagie Gymnosomata. Organizmy te maja swych przedstawicieli we wszystkich rejonach oceanu światowego, jednak kilkanaście gatunków masowo występuje również w rejonach polarnych (VAN DER SPOEL 1967, 1976). Organizmy te charakteryzuja się wysoka wrażliwościa na nawet niewielkie zmiany temperatury czy zaburzenia chemizmu wód. Ślimaki skrzydłonogie stanowią ważna grupę organizmów w pelagialu wszystkich oceanów, będacc istotnym ogniwem polarnych i subpolarnych sieci troficznych. Zazwyczaj tworza zgrupowania, które sa źródłem pokarmu dla waleni, ptaków morskich i różnych gatunków ryb, w tym także poławianych komercyjnie (CONOVER i LALLI 1972, LARSON i HARBISON 1989). W północnym Atlantyku głównymi organizmami żerujacymi na Pteropoda $z$ rodzaju Limacina, sa między

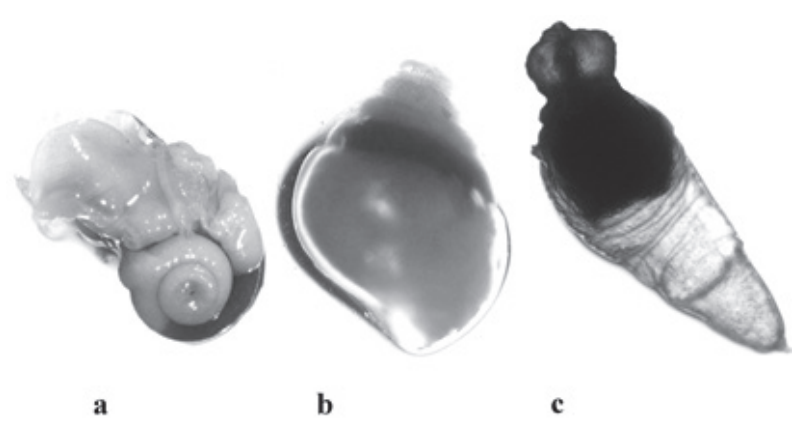

Ryc. 1 Ślimaki skrzydłonogie występujące w rejonie Arktyki a - Limacina helicina, b - Limacina retroversa, c - Clione limacina 
innymi śledź, makrela czy młodociane formy dorsza i karmazyna (LEBOUR 1932, BAINBRIDGE i MCKAY 1968). Co więcej, HARDY (1924) oszacował, że Limacina retroversa stanowiła około $2,2 \%$ rocznego źródła pokarmu dla śledzia w Morzu Północnym, natomiast ITO (1964) odnotował, że dla lososia pacyficznego głównym składnikiem diety jest gatunek $L$. helicina. Doniesienia te potwierdzaja również FABRY i współaut. (2008), którzy zaobserwowali ślimaki $\mathrm{w}$ diecie młodocianego łososia pacyficznego $\mathrm{z}$ udziałem powyżej 60\%. W Oceanie Południowym Thecosomata sa zjadane przez różne grupy należące do zooplanktonu, takie jak Gymnosomata, salpy czy kryl. Natomiast Euphausia super$b a$, obunogi, głowonogi, stanowia pokarm dla ryb pelagicznych i demersalnych oraz ptaków morskich (HOPKINS i TORRES 1989, HUNT i współaut. 2008, LANCRAFT i wspó1aut. 1991). Niezwykle ważną rolę zwierzęta te pełnia również $\mathrm{w}$ cyklach biogeochemicznych. Ślimaki przyczyniaja się do znacznej sekwestracji węgla (wychwycenie oraz zdeponowanie) jako konsument fitoplanktonu, ale również poprzez tworzenie pelet fekalnych, muszli czy sieci śluzowych (NOJI i współaut. 1997, TsuRumi i współaut. 2005, HUNT i współaut. 2008, MANNO i współaut. 2010). Zmiany w gospodarce węglanowej oceanów stanowia wyzwanie dla Pteropoda, ze względu na wytwarzane przez nie muszle. Sa one zbudowane $z$ aragonitu, mniej stabilnej formy węglanu wapnia, który jest o około $50 \%$ bardziej rozpuszczalny w wodzie morskiej niż kalcyt (MUCCI 1983). Liczebność populacji gatunków $\mathrm{z}$ rodzaju Limacina zdecydowanie zmniejszyła się $\mathrm{w}$ wodach północnego Pacyfiku, w okolicy Wyspy Vancouver (MACKAS i GALBRAITH 2012), oraz w północnym Atlantyku (BEAUGRAND i współaut. 2013). Opisana sytuacja miała zwiazek nie tylko z zakwaszeniem wód, ale również $z$ innymi czynnikami stresowymi, takimi jak wzrost temperatury wód (BEAUGRAND i współaut. 2013). Z kolei w Morzu Północnym BeARe i współaut. (2013) odnotowali długoterminowy spadek liczebności Pteropoda, będący wynikiem wzajemnego oddziaływania wielu czynników środowiskowych, takich jak: temperatura, występowanie składników odżywczych i obecność drapieżników. Jak podaja autorzy, obniżone $\mathrm{pH}$ w mniejszym stopniu wpłynęło na występowanie omawianej grupy zwierzat, jednak zaznaczają konieczność ciagłego monitorowania zakwaszenia wód i gospodarki węglanowej tego rejonu. Co więcej, nie wszędzie populacje Pteropoda ulegaja wpływom zmieniajacego się klimatu. Thecosomata, zasiedlajace wody w pobliżu Półwyspu Antarktycznego, nie wykazywały długoterminowych spadków liczebności (LOEB i SANTORA
2013). Pteropoda maja możliwość przesuwania zasięgów występowania w rejony bardziej sprzyjajace ich prawidłowemu funkcjonowaniu. Jednak dużo trudniejsze wydaje się określenie, jak zdarzenia te moga wygląać w rzeczywistości. Niektóre badania donosza, że zasięgi występowania Pteropoda w Oceanie Poludniowym będa przesuwaly się $\mathrm{w}$ kierunku północnym, a więc $\mathrm{w}$ obszary wód zakwaszonych w mniejszym stopniu (HUNT i współaut. 2008, COMEAU i współaut. 2012). $Z$ drugiej jednak strony, ze względu na waskie wymagania termiczne, migracja $\mathrm{w}$ kierunku północnym może być utrudniona lub wręcz niemożliwa (FABRY i współaut. 2008). Busch i współaut. (2015) w Cieśninie Fram (Arktyka), podczas czteroletnich badań, zaobserwowali znaczne przesunięcie zasięgu borealnego gatunku Limacina retroversa $\mathrm{w}$ kierunku północnym, a więc tym samym zastępowanie zimnolubnego gatunku Limacina helicina. Zdaje się to potwierdzać obserwowana $\mathrm{w}$ ostatnich latach dominacje borealnych gatunków subarktycznych w rejonach Arktyki wysokiej.

W zwiazku $z$ powyższym, chcac poznać odpowiedzi organizmów na zmiany zachodzące $\mathrm{w}$ środowisku morskim, należy zwrócić uwage na wiele złożonych aspektów. Niezbędna wydaje się analiza procesów na poziomie gatunkowym, jak również ekosystemowym. Ze względu na różną wrażliwość poszczególnych stadiów rozwojowych na modyfikacje parametrów fizyko-chemicznych, a także zaburzenia procesów fizjologicznych (opóźnienie rozrodu lub wylęgu młodych, degradacja elementów wapiennych szkieletu, stres oksydacyjny), jak również zmiany zasięgów występowania czy liczebności, powoduja, że prowadzone badania i monitoring powinny mieć charakter kompleksowy.

Streszczenie

Od czasu Rewolucji Przemysłowej Ocean Światowy doświadcza gwałtownych zmian związanych przede wszystkim $z$ ociepleniem wód, ale również zjawisk temu towarzyszacych jak zakwaszanie spowodowane nadmiernym absorbowaniem atmosferycznego $\mathrm{CO}_{2}$ Istotnym jest, iż przekształcenia $\mathrm{w}$ ekosystemach pelagialu zachodza nie tylko w rejonach polarnych, ale również w innych rejonach swiata. Wynika to $z$ globalnie działajacej cyrkulacji atmosferycznej, której oddziaływanie obserwowane jest w całym Oceanie Światowym. Zarówno w Arktyce jak i Antarktyce, zmniejszajacy się zasięg lodu morskiego i cielenie lodowców maja wpływ na przebieg produkcji pierwotnej, a co za tym idzie, na funkcjonowanie wyższych poziomów troficznych, zaczynając od zooplanktonu a kończac na ssakach morskich. Obserwacje zmian klimatu, najbardziej widoczne w ekosystemach polarnych, spowodowały wzrost zainteresowania biologów morskich reakcja organizmów morskich na zachodzące procesy, szczególnie zooplanktonu. Ich znaczenie w sieci troficznej oraz zwykle zawężone zakresy tolerancji na czynniki abiotyczne i biotyczne powoduja, że sa one kluczo- 
wym elementem monitoringu ekosystemowego. Skutkiem przemian środowiska jest, między innymi, przesuwanie zasięgów występowania wielu gatunków, szczególnie bytujących w rejonach polarnych, ale również liczne odpowiedzi organizmów reagujących na stopniowe zakwaszanie oceanów. Najbardziej narażone będa organizmy których tkanki zbudowane sa częściowo $\mathrm{z} \mathrm{CaCO}_{3}$ jak otwornice, kokolitofory, szkarłupnie czy ślimaki pelagiczne, ale również te które sa stenobiontyczne jak polarne gatunki widłonogów czy kryl antarktyczny, stanowiące główny element łańcucha troficznego. W niniejszym artykule przedyskutowano konsekwencje procesów takich jak ocieplenie wód oraz ich zakwaszenie dla licznych organizmów morskich oraz ich potencjalne reakcje na negatywne bodźce. Liczne badania pokazuja, iż niewielki nawet spadek $\mathrm{pH}$ wód morskich i podwyższenie ich temperatury, powoduja zaburzenia fizjologii zamieszkujących je organizmów, a także zmiany zasięgów ich występowania czy liczebności.

\section{LITERATURA}

Arrigo K. R., Van DiJken G. L., Ainley D. G., FAHNESTOCK M. A, MARKUS T., 2002. Ecological impact of a large Antarctic iceberg. Geophys. Res. Lett. 29, doi.org/10.1029/2001GL014160.

BAINBRIDGE V., MCKAY B. J., 1968. The feeding of cod and redfish larvae. Int. Comm. NW Atlantic Fish. Spec. Publ. 7, 187-217.

BarnetT T. P., PIERCE D. W., AChUTARao K. M., Glecker P. J., SANTER B. D., Gregory J. M., WASHington W. M., 2005. Penetration of human - induced warming into world's oceans. Science 309, 284-287.

BAtes N. R., MATHIS J. T., COOper L. W., 2009. Ocean acidification and biologically induced seasonality of carbonate mineral saturation states in the western Arctic Ocean. J. Geophys. Res. 114, C11007.

Beare D., MCQuaTters-Gollop A., VAN DER HAMMEN T., MACHIElS M., TEOH S. J., HALl-SPENCER J. M., 2013. Long-term trends in calcifying plankton and $\mathrm{pH}$ in the North Sea. PLoS One 8.

BEAUGRAND G., KIRBY R. R., 2010. Spatial changes in the sensitivity of Atlantic cod to climate-driven effects in the plankton. Clim. Res. $41,15-19$.

BEAUGRAND G., MCQUATTERS-GOLLOP A., EDWARDS M., GoBerVille E., 2013. Long-term responses of North Atlantic calcifying plankton to climate change. Nat. Clim. Change 3, 263-267.

BRIERLEY A. S., KINGSFORD M. J., 2009. Impacts of climate change on marine organisms and ecosystems. Curr. Biol. 19, R602-R614.

Busch D. S., Maher M., Thibodeau P., McElhany P., 2014. Shell condition and survival of Puget sound pteropods are impaired by ocean acidification conditions. PLoS One 9.

CHOWN S. L., Clarke A., Fraser C. I., CARY S. C., Moon K. L., McGEOCH M. A., 2015. The changing form of Antarctic biodiversity. Nature $522,431-438$.

COMEAu S., Gatusso J.-P., NisumaA A.-M., ORR J., 2012. Impact of aragonite saturation state changes on migratory pteropods. Proc. Royal Soc. B, Biol. Sci. 279, 732-738.

Conover R. J., LALLI C. M., 1972. Feeding and growth in Clione limacina (Phipps), a pteropod mollusk. J. Exp. Marine Biol. Ecol. 9, 279302.
DUTKIEWICZ S., MORRIS J. J., FOLLOWS M. J., SCOTT J., LEVITAN O., DYHRMAN S. T., BERMAN-FRANK I., 2015. Impact of ocean acidification on the structure of future phytoplankton communities. Nat. Clim. Change 5, 10021006.

FABRY V. J., SeIBel B. A., Feely R. A., ORR C. J., 2008. Impacts of ocean acidification on marine fauna and ecosystem process. ICES J. Marine Sci. 65, 414-432.

FeEly R. A., Sabine C. L., Kitack L, Berelson W., Kleypas J., FABRy V. J., Millero F. J., 2004. Impact of anthropogenic $\mathrm{CO}_{2}$ on the $\mathrm{CaCO}_{3}$ system in the oceans. Science 305, 362-366.

FEely R. A., ORR J., FABRy V. J., Kleypas J. A., SABINE C. L., LANGDON C., 2009. Present and future changes in seawater chemistry due to ocean acidification. [W:] Carbon sequestration and its role in the global carbon cycle. MCPHERSON B. J., SUNDQUIST E. T. (red.). Geophys. Monogr. Ser. 83. American Geophysical Union, Washington, DC.

FLYNN K. J., BLACKFORD J. C., BAIRD M. E., RAVEN J. A., Clarke D. R., BeARdall J., BRownleE C., Fabian H., Wheeler G. L., 2012. Changes in the $\mathrm{pH}$ in the exterior surface of plankton with ocean acidification. Nat. Clim. Change 2, 510-513.

FlynN K. J., Clark D. R., Mitra A., FABIAN H., Hansen P. J., GliberT P. M., WheEler G. L., STOECKER D. K., BLACKFORD J. C., BROWNLEE C., 2015. Ocean acidification with (de) eutrophication will alter future phytoplankton growth and succession. Proc. Royal Soc. B 282, 20142604.

GARZKe J., HANSEN T., ISMAR S. M. H., SOMMER U., 2016. Combined effects of ocean warming and acidification on copepod abundance, body size and fatty acid content. PLoS One 11, e0155952.

GRUBER N., 2011. Warming up, turning sour, losing breath: ocean biogeochemistry under global change. Phil. Transact. Royal Soc. A 369, $1980-1996$.

HARDY A. C., 1924. The herring in relation to its animate environment. Part I. The food and feeding habits of the herring with special reference to the East Coast of England. Fishery Investment, London 2, 1-53.

HIRCHE H.-J., 1997. Life cycle of the copepod Calanus hyperboreus in the Greenland Sea. Mar. Biol. 128, 607-618.

HopkINS T. L., TORRES J. J., 1989. Midwater food web in the vicinity of a marginal ice zone in the western Weddell Sea. Deep Sea Res. A. Oceanogr. Res. Pap. 36, 543-560.

Hunt B. P. V., PAKHOMOV E. A., Hosie G. W., Siegel V., Ward P., Bernard K., 2008. Pteropods in the southern ocean ecosystems. Progr. Oceanography 78, 193-221.

IPCC, 2013. Climate change 2013: the physical science basis. [W:] Contribution of Working Group 1 to the Fifth Assessment Report of the Intergovernmental Panel on Climate Change. MIDGLEY P. M. (red.). Cambridge University Press, Cambridge, UK.

ITO, J., 1964. Food and feeding habit of Pacific salmon (genus Oncorhynchus) in their oceanic life. Bull. Hokkaido Reg. Fish. Lab. Res. 29, 85-97.

KeEling R. F., Kortzinger A., GRUber N., 2010. Ocean deoxygenation in a warming world. Annual Review of Marine Science 2: 199-229.

Khatiwala, S., Primeau F., Hall T., 2009. Reconstruction of the history of anthropogenic 
CO concentrations in the ocean. Nature 462, 346-349.

KROEKER K. J., KORDAS R. L., CRIM R, HENDRIKS I. E., Ramajo L., Singh G. S., Duarte C. M. GATUSSO J. P., 2013. Impacts of ocean acidification on marine organisms: quantifying sensitivities and interaction with warming. Global Change Biol. 19, 1884-1896.

LANCRAFT T. M., HOPKINS T. L., TORRES J. J., DONNELlY J., 1991. Oceanic micronektonic/ macrozooplanktonic community structure and feeding in ice covered Antarctic waters during the winter (AMERIEZ 1988). Polar Biol. 11, 157-167.

LARSON R. J., HARBISON G. R., 1989. Source and fate of lipids in polar gelatinous zooplankton. Arctic 42, 339-346.

LEBOUR M. V., 1932. Limacina retoversa in Plym outh Waters. J. Marine Biol. Ass. United Kingdom 18, 123-126.

Loeb V. J., SANTORA J. A., 2013. Pteropods and climate off the Antarctic Peninsula. Progr. Oceanography 116, 31-48.

MAas A. E., Wishner K. F., Seibel B. A., 2012. Metabolic suppression in the thecosomatous pteropods as an effect of low temperature and hypoxia in the eastern tropical North Pacific. Marine Biol. 159, 1955-1967.

Mackas D. L., Galbraith M. D., 2012. Pteropod time - series from the NE Pacific. ICES J. Marine Sci. 69, 448-459.

Manno C., Tirelli V., Accornero A., Fonda UmaNI S., 2010. Importance of the contribution of Limacina helicina faecal pellets to the carbon pump in Terra Nova Bay (Antarctica). J. Plankt. Res. 32, 145-152.

MUCCI A., 1983. The solubility of calcite and ara gonite in seawater at various salinities, temperatures and one atmosphere total pressure. Am. J. Sci. 283, 780-799.

NoJi T. T., BATHMANN U. V., VON BOdungen B., Voss M., Antia A., Krumbholz M., Klein B., PEeKen I., NoJi C. I.-M., ReY F., 1997. Clearance of picoplankton - sized particles and for mation of rapidly sinking aggregates by the pteropod, Limacina retroversa. J. Plankton Res. 19, 863-875.

ORR C. J., FABRY V. J., AUMONT O., BOPP L., DONEY S. C., FEely R. A., GNANADESIKAN A., GRUBer N., ISHIDA A., JoOs F., KEY R. M., LiNDSAY K., MAIER-REIMER E., MATEAR R., MONFRAY P., MOUCHET A., NAIJAR R. G., PlaTTNER G.-K, RODGERS K. B. SABINE C. L., SARMiEnto J. L., Schlitzer R., Slater R. D., TOTTERDELL I. J., WEIRIG M.-F., YAMANAKA Y., Yool A., 2005. Anthropogenic ocean acidification over twenty-first century and its impact on calcifying organisms. Nature 437, 681-686.
PAKHOMOV E. A., 2011. Demography and life cycle of Antarctic krill, Euphausia superba, in the Indian sector of the Southern Ocean: long-term comparison between coastal and open-ocean regions. Canad. J. Fish. Aqu. Sci. 57, 68-90.

POlOCZANSKA E. S., BuRRows M. T., BROWN C. J., Molinos J. G., HAlPern B. S., HoEGH-GuldBERG O., KaPPEL C. V., MOORE P. J., RichARDSON A. J., SchOEMAN D. S., SYdEMAN W. J., 2016. Responses of marine organisms to climate change across oceans. Front. Marine Sci. 3, 62 .

SABINE C. L., FEely R. A., 2007. The oceanic sink for carbon dioxide. [W:] Greenhouse Gas Sinks. SMITH K. (red.). CABI Publishing, Oxfordshire, UK, 31-49.

SEIBEL B. A., 2011. Critical oxygen levels and metabolic suppression in oceanic oxygen minimum zones. J. Exp. Biol. 214, 326-336.

SCHIEBEL R., 2002. Planktonic foraminiferal sedimentation and the marine calcite budget. Global Biogeochem, Cycles 16, doi.org/ 10.1029/2001GB001459.

ScotT C. L., KWAŚNIEWSKI S., FALK-PETERSEN S., SARGENT J. R., 2000. Lipids and life strategies of Calanus finmarchicus, Calanus glacialis, and Calanus hyperboreus in late autumn, Kongsfjorden, Svalbard. Polar Biol. 23, 510516.

Steinacher M., Joos F., Frolicher T. L., PlatTNER G.- K., DONEY S. C., 2009. Imminent ocean acidification in the Arctic projected with the NCAR global climate carbon cycle - climate model. Biogeosciences 6, 515-533.

TSurumi M. Mackas D. L., Whitney F. A., DiBacCO C., Galbraith M. D., WONG C. S., 2005. Pteropods, eddies, carbon flux, and climate variability in the Alaska Gyre. Deep Sea Res. Part II, 52, 1037-1053.

Turner J., HuA L., White I., KIng C. J., PhILlips T., Hosking S. J., BRacegirdle J. T., MaRSHAll J. G., Mulvaney R., PranaB D., 2016. Absence of 21 st century warming on Antarctic Peninsula consistent with natural variability. Nature 535, 411-415.

VAN DER SPOEL S., 1967. Euthecosomata a group with remarkable developmental stages (Gastropoda, Pteropoda). Bohn, Scheltema \& Holkema, Utrecht.

VAN DER SPOEL S., 1976. Pseudothecosomata, Gymnosomata and Heteropoda. Bohn, Scheltema \& Holkema, Amsterdam.

WEYDMANN A., SøREIDE J. E., KWAŚNIEWSKI S., WIDDICOMBE S., 2012. Influence of $\mathrm{CO}_{2}$-induced acidification on the reproduction of a key Arctic copepod Calanus glacialis. J. Exp. Marine Biol. Ecol. 428, 3- 42. 
KOSMOS Vol. $67,4,749-757,2018$

Paula Kacprzak, Justyna Wawrzynek, Angelika SŁomska

Department of Marine Plankton Research, Institute of Oceanography, University of Gdańsk, 46 Marszałka Piłsudskiego Al., 81-378 Gdynia, E-mail: paula.kacprzak@phdstud.ug.edu.pl

\section{ZOOPLANKTON IN POLAR REGIONS - CHALLENGES AND FORECASTS IN THE FACE OF CLIMATE CHANGES}

\section{Summary}

Since the beginning of the Industrial Revolution the world ocean is experiencing rapid changes like warming and accompanying events e.g. acidification of water masses due to absorption of atmospheric CO2. The most important fact is that modifications of pelagic ecosystems take place not only in the polar regions, but also in other regions of the world. This is the result of global atmospheric circulation which provides processes visible in the whole World Ocean. In the Arctic Ocean as well as in the Antarctic region, depletion of the extent of sea ice and iceberg calving have crucial impact on dynamics of primary production and, in consequence, functioning of higher trophic levels, from zooplankton to sea mammals. Observations of climate changes, most visible in the polar regions, brought about among marine biologists particular interest in responses of marine organisms, especially zooplankton, to these processes. The important role played by zooplankton in the food web and narrow ranges of tolerance thereof to abiotic and biotic factors makes these organisms the key element of ecosystem monitoring. Environmental modifications affected by ocean acidification result inter alia in changes of species distribution ranges, especially in the polar regions. The most vulnerable are not only organisms built partially of $\mathrm{CaCO} 3$ e.g. foraminifers, cocolithophors, echinoderms and pelagic snails, but also stenobiotic ones like polar species of copepods and Antarctic krill, the main elements of pelagic food chain. In this article, we discuss ecological consequences of these processes.

Key words: acidification, climate changes, polar regions, pteropods, zooplankton 